\title{
Pine SAP cultivation partnership pattern in the Forest Management Unit of Central Mamasa
}

\author{
Trivena ${ }^{1}$, Muhammad Dassir ${ }^{2}$, Andi Mujetahid ${ }^{3}$ \\ ${ }^{1}$ Forestry Study Program, Graduate School Hasanuddin University, Makassar, 90245, Indonesia \\ ${ }^{2}$ Forestry Study Program, Graduate School Hasanuddin University, Makassar, 90245, Indonesia \\ ${ }^{3}$ Forestry Study Program, Graduate School Hasanuddin University, Makassar, 90245, Indonesia
}

Corresponding Author: Trivena, Forestry Study Program, Graduate School Hasanuddin University, Makassar, 90245, Indonesia

E-mail: trivena25@gmail.com

Received date: 28 August 2019, Accepted date: 13 December 2019, Online date: 20 December 2019

Copyright: (C) 2019 Trivena et al., This is an open-access article distributed under the terms of the Creative Commons Attribution License, which permits unrestricted use, distribution, and reproduction in any medium, provided the original author and source are credited.

\begin{abstract}
The development of forest management units provides opportunities for forest exploitation and the parties to manage forest resources in accordance with their characteristics and still empower the communities surrounding the forest. The research aims to determine the pattern of partnership used in pine tapping activities and to analyze the development of the partnership pattern. The study was conducted for four months from April to 2019 July. The population of this research, namely pine farmers, corporations, forest management in the central Mamasa Union, and related stakeholders in forestry management and decisionmakers. Data collection is done with in-depth interviews, focused group discussions, and observations. Data analysis is done in qualitative and quantitative analysis. The results of this study show that the pattern of pine tapping Partnership is a pattern of partnership between farmers, PT. Kencana Hijau Bina Lestari with KPH Central Mamasa and a pattern of partnership between the tapping of farmers, capital owners, PT. Kencana Hijau Bina Lestari With the Mamasa Central forest management unit. The formulation of partnership pattern is with the priority direction of readiness of human resources, funding sources, socialization and mentoring, cooperation agreements and evaluation and monitoring of activities.
\end{abstract}

Keywords: Partnership, AHP, Pine

\section{INTRODUCTION}

The formation of forest management Units (KPH) provides forest mastery opportunities and opportunities for the parties to participate in forest resource management following its resource characteristics [1]. Therefore, the KPH as a forest management unit on site is considered a strategic solution. The development of KPH in the future is expected to be semiindependent institutions both financially and professionally able to accommodate the ecological, social and economic aspects that should be able to provide a rapid response to the needs of the field [2]. To realize the potential in the KPH region must support the KPH of the independent centre of Mamasa. One potential while developed today is the SAP pine. Pine SAP tapping at the central kph of Mamasa has not been optimally seen from the lack of interest of local people to tap this sap seen from the number of buts imported by the company much more than the local people with much different production results [ 3]. This is due to a lack of interest in local people in the tapping of pine sap and the absence of coaching to farmers in suppressing activities.

On the other hand, the removal of pine forests for the SAP pine Tapping activities tends to exploit resources without the balance of security and harvest to get a lot of production results without regard to the rules related to sustainability and Sustainability of natural resources [4]. Without good management, changes in the value of a pine plant the potentially cause the loss of pine plants in a period not too long, because the parties tend to make a lot of profit in a short period, And not think of the pine forests that currently exist due to the ecological process for decades. Due to the effort to have a high economic value, there is long and medium-term planning that is based on accurate data, involving local communities, the central Mamasa KPH, the corporate Party and Government in a pattern of partnership with community-based forest management. Local communities participate in the program to gain management rights and minimize conflicts [5]. Through the associations of communities around the forest can coexist with the company in managing and forestry economically and still consider the sustainability of forests [6].

The management unit of Central Mamasa Forest as one of the forest managers at the site level is given the authority by the State to manage forests to improve the welfare of the people, to donate revenue to the country and become a manager Forest resource sustainability aspect. But in reality, if it is reviewed from the economic aspect, there are still many people from lowincome forest areas [7]. 
The aims of this research was to determine the pattern of Pine SAP Business partnership in the Union of Central Mamasa Forest management; This research aims to identify the pattern of alliances used in the activities of tapping the pine SAP and to analyze the formulation of partnership development pattern. The results of this research are expected to be used by the unity of forest management and to be input to the central and local governments in the decision-making forest management at the location level.

\section{RESEARCH METHODOLOGY}

This research was conducted in the working area of the unification of the Mamasa Forest of central Mamasa regency of West Sulawesi Province in April-July 2019. The research methodology is conducted in qualitative descriptive and quantitative analysis. The population of this research is SAP pine tree, company, forest management of Mamasa Central area, and related stakeholders in forestry management and decision-maker. Primary data collection is done with in-depth interviews with the help of questionnaires, Focus Group Discussion (FGD), and direct observation, while secondary data is used as the main data that supports data obtained from literary studies and Institutions that support this research.

Sampling area determination is done by purposely sampling with certain considerations [8]. The selection of research sites was chosen intentionally based on the SAP pine tapping activity while the respondent in this research is farmer farmers 25 people, the centre of Mamasa KPH 5 people, PT. Kencana Hijau Bina Lestari 5 people, the Village head and forestry service of West Sulawesi province 1 person.

The data analysis used is a qualitative descriptive to know the pattern of the Pine SAP Administration Partnership and the Process hierarchy Analysis (AHP) with the software expert choice 11.

\section{RESULTS AND DISCUSSION}

The development of pine forest management in the middle of central Mamasa forest management has been started since 2010 through pine SAP activities. The government of Mamasa started to create a pine forest reserve in 2010 by issuing pine SAP clearance to the PT. Milatronika Karya Niaga. Along with the regulatory and legal changes Disthe. No. 23 the year 2014 , where forestry affairs turned to the province then the permits issued by the district government no longer apply. In the year 2017 , the provincial government of West Sulawesi issued the license to wiretapping pine resin in the area of central Mamasa forest management to PT. Kencana Hijau Bina Lestari in accordance with cooperation agreement number: 415. A/33/KPH-MT/7/2017 and Number: 029/KHBL-KPH/SB/MTE/IV/2017. In the Year 2018 Directorate General of River Basin control and protected forest Ministry of Environment and Forestry and PT. Kencana Hijau Bina Lestari makes cooperation agreement with the number: MCC. 17/PDASHL/SET/KUM. 3/12/2018, Number: 013/KHBL/HO/XII/18 on the cooperation of Pine SAP Poll on the unity of forest management in central Mamasa province, West Sulawesi with an area of about 4,000 ha (4000 hectares).

Cooperation agreement that has been issued by the Ministry of Environment and Forestry, which is guided by the regulation of the Minister of Environment and forestry number: P. 49/MENLHK/SETJEN/KUM. I/9/2017 on the cooperation of forest management in the forest management unit is supported by a memorandum of understanding between the Forestry service of West Sulawesi Province and PT. Kencana Green Bina Lestari Number: 008/DISHUT/SPPBH-I/2019: Number 009/KHBL/HO/I/2019 on financing systems and the pattern of cooperation of Pine SAP poll in the area of technical implementation of forest management Unit of central Mamasa in West Sulawesi province.

Follow up cooperation agreement between the Ministry of Forestry and Environment and Forestry Department of West Sulawesi Province with PT. Kencana Hijau Bina Lestari, KPH of Mamasa made an operational cooperation agreement between the Technical Implementation Unit of Dinas (UPTD) of the central forest management of Mamasa with PT. Kencana Hijau Bina Lestari Number: 415.4/157/KPH-MT/PKSO-XII/2019 and Number: 018/KHBL/HO/XII/2018 at Pine SAP Poll in UPTD area, central Sulawesi Barat province, which The SAP Pine (KPH) in the centre of Mamasa [9].

Pine SAP intercepts activities in the forest management unit of Central Mamasa were found in 11 (eleven) villages, 4 sub-districts: Messawa Sub-district located in the village of Sepang, Tanete Stone Village, Matande village, Makuang Village, and Rippung village with a total of 52 people. Sumarororong District is located in Sibanawa village and is a village with a total of about 31 people. The district of Tandukkalua is located in the villages of Balabatu and Salurano with a Total of 15 people, while Balla Sub-district is located in the village of West Balla and Pidara with a total of about 20 people, so the number of local population 118 people and migrants is about 31 people.

\section{Pine SAP Tapping Partnership pattern at KPH Central Mamasa}

The pattern of cooperation between farmers and corporations in the Union of Central Mamasa forest management is a pattern of subcontracting partnerships which is a partnership relationship between group Partners and company Partners in which the group manufacturing partner components are required Of the company as part of the production. The indicator of this partnership pattern is a joint contract containing the price and time between the company and the partner Group [10].

The first partnership pattern is entrusted part manufacture, which applies to the group of companies, this usually comes from the island of Java and currently amounted to 31 people located in the area of forest management unit of central Mamasa. For the needs of living farmers who stir for two weeks will be borne by the company and will be returned by the farmer when harvesting the rubber, while the facilities and infrastructures used in the rubber tapping on the full responsibility by PT. The 
green Kencana Bina Lestari, but farmers must fulfil the number of production targets that have been agreed with the time period and the price of rubber that has been agreed. In this pattern, the unity of forest management of central Mamasa provides land that will be the location of awareness and conduct monitoring and security activities of the Pencyang activities, during the party of PT. Kencana Hijau Bina Lestari obliged to pay To the Central Mamasa forest management unit as much as $2.5 \%$ per kilogram of rubber in production according to the current price of the rubber market.

The second partnership pattern is between farmers or communities, capital owners, PT. Kencana Hijau Bina Lestari with the unity of forest management Central Mamasa in the tapping of pine sap. The owner of the capital comes from local people and farmers who knock from the surrounding community, cooperate in the form of entrusted part manufacture, capital owners prepare the form of facilities and infrastructure that farmers need to do to implement Intercepted activities while the stirring farmers are obliged to sell rubber to the capital owners. While the owners of capital and PT. Kencana Hijau Bina Lestari has a cooperative relationship as a seller and buyer.

The unity of forest management of central Mamasa with PT. Kencana Hijau Bina Lestari has a pattern of cooperation in the form of business operations, namely the unity of forest management of Mamasa central to prepare the land, manpower, and administration services, and provide Dissemination to prospective farmers, during PT. Kencana Hijau Bina Lestari Prepare the cost or business capital and means to carry out the activities.

\section{Formulation pattern of pine SAP tapping Partnership}

The formulation of a partnership pattern begins with the dominant criteria and is required in determining the main problem by structuring the solution priority. Build process hierarchy with AHP method to get the important scale, so that obtained criteria, sub-criterion or alternative that is the highest priority [11] In order to develop the exploitation pattern of pine resin pattern presented in the picture below.

Test calculations and consistency are repeated for all criteria. The calculations and weights and assessments of relative inconsistency are in pairs for each criterion in the tree hierarchy. The resulting weights to be the basis of calculation of the priority synthesis are done to produce the best alternative sequence for the Pine SAP Tapping formula of partnership pattern in the forest management unit of central Mamasa.

Based on the results of analysis on the criteria obtained weight ordered from highest to lowest, namely: readiness of human resources have the highest weight of 0484 , funding source 0208 , socialization and mentoring 129 , cooperation agreement 0188, Monitoring and evaluation of 0.61 , and has a consistency value of 0.00 (Table 2). This means that by using consistency tests or scale-determination interests towards the respondent's criteria it is said to be consistent because the value is less than 0.1 [11].

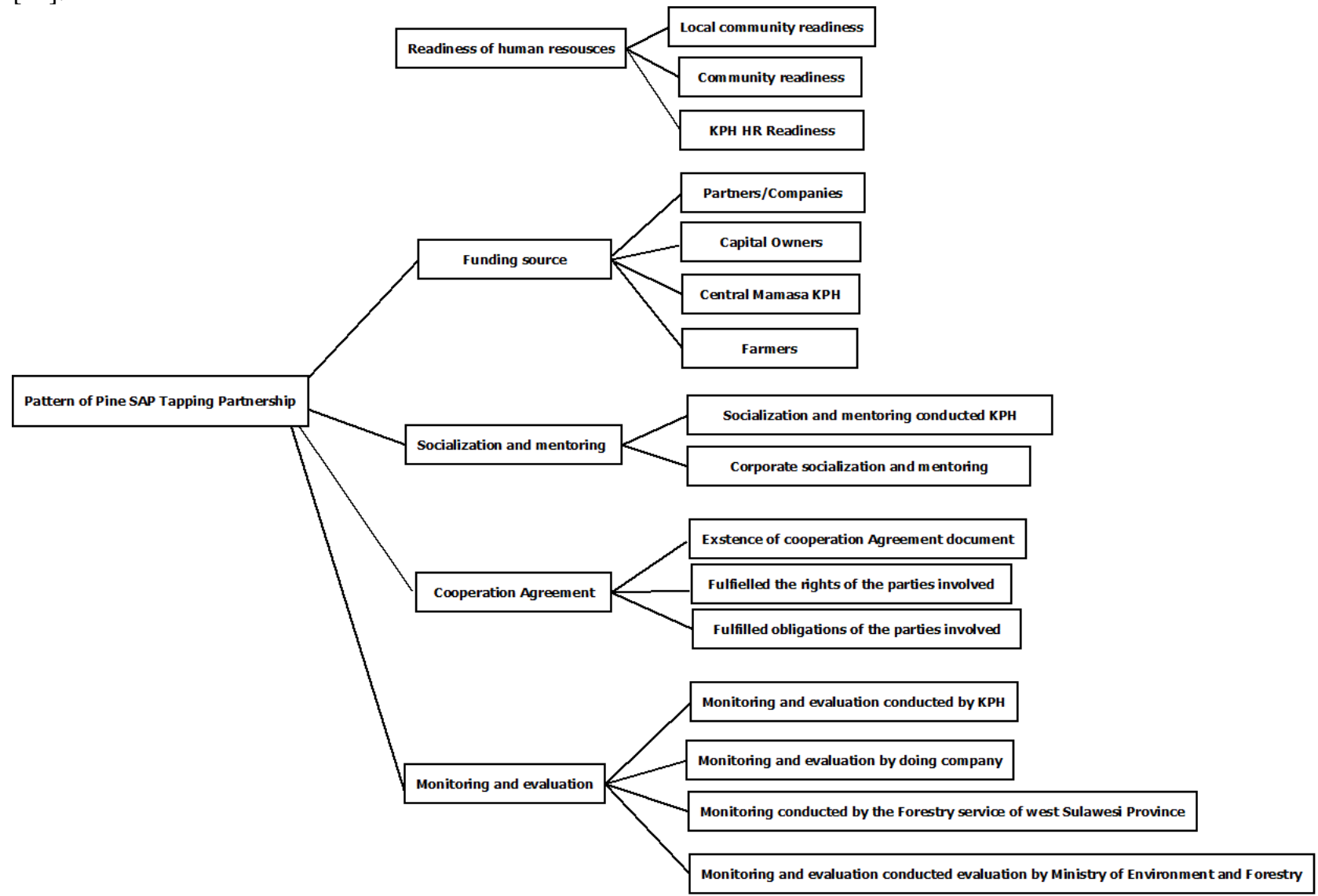

Image of the hierarchy analysis of AHP 
Table 1. The results of a weighted matrix of pine resin in a partnership pattern at forest management of central Mamasa

\begin{tabular}{llll}
\hline \multicolumn{1}{c}{ Criteria } & Weight & Priority Prioritas & Consistency Ratio \\
\hline Readiness of human Resources & 0.484 & 1 & 0.09 \\
\hline Funding source & 0.208 & 2 & 0.09 \\
\hline Socialization and mentoring & 0.129 & 3 & 0.00 \\
\hline Cooperation Agreement & 0.118 & 4 & 0.00 \\
\hline Monitoring and evaluation & 0.061 & 5 & 0.05 \\
\hline
\end{tabular}

Based on the weight of the results in the table above indicates that the human resource readiness criteria have the highest weight. This indicates that these criteria are very large and can intervene in other criteria. While the weighted results of each sub-criterion or alternative are presented in the following table 2 :

Table 2. Results of weighted matrix sub-criteria of pine resin Administration Partnership pattern at forest management of central Mamasa

\begin{tabular}{|c|c|c|c|c|}
\hline Criteria & Weight & $\begin{array}{l}\text { Priority } \\
\text { Prioritas }\end{array}$ & $\begin{array}{l}\text { Consistency } \\
\text { Ratio }\end{array}$ & Criteria \\
\hline \multirow{3}{*}{$\begin{array}{l}\text { The readiness of } \\
\text { human } \\
\text { Resources }\end{array}$} & Local community Readiness & 0.230 & 2 & \multirow{3}{*}{0.07} \\
\hline & Community Readiness & 0.088 & 3 & \\
\hline & KPH HR Readiness & 0.682 & 1 & \\
\hline \multirow{4}{*}{ Funding source } & Partners/Companies & 0.503 & 1 & \multirow{4}{*}{0.07} \\
\hline & Capital Owners & 0.259 & 2 & \\
\hline & Central Mamasa KPH & 0.155 & 3 & \\
\hline & Farmer & 0.082 & 4 & \\
\hline \multirow{2}{*}{$\begin{array}{l}\text { Socialization } \\
\text { and mentoring }\end{array}$} & $\begin{array}{l}\text { Socialization and mentoring conducted } \\
\text { KPH }\end{array}$ & 0.827 & 1 & \multirow[t]{2}{*}{0.00} \\
\hline & Corporate socialization and mentoring & 0.173 & 2 & \\
\hline \multirow{3}{*}{$\begin{array}{l}\text { Cooperation } \\
\text { Agreement }\end{array}$} & $\begin{array}{l}\text { Existence of cooperation Agreement } \\
\text { documents }\end{array}$ & 0.747 & 1 & \multirow{3}{*}{0.00} \\
\hline & Fulfilled the rights of the parties involved & 0.126 & 2 & \\
\hline & Fulfilled obligations of the parties involved & 0.126 & 2 & \\
\hline \multirow{4}{*}{$\begin{array}{l}\text { Monitoring and } \\
\text { evaluation }\end{array}$} & $\begin{array}{l}\text { Monitoring and evaluation conducted by } \\
\mathrm{KPH}\end{array}$ & 0.615 & 1 & \multirow{4}{*}{0.00} \\
\hline & $\begin{array}{l}\text { Monitoring and evaluation by doing } \\
\text { company }\end{array}$ & 0,117 & 3 & \\
\hline & $\begin{array}{l}\text { Monitoring conducted by the Forestry } \\
\text { service of West Sulawesi province }\end{array}$ & 0.189 & 2 & \\
\hline & $\begin{array}{l}\text { Monitoring and evaluation conducted by } \\
\text { the Ministry of Environment and Forestry }\end{array}$ & 0.079 & 4 & \\
\hline
\end{tabular}

Table 2 shows a combination of partnership patterns by developing existing partnership patterns, with dominant or priority criteria which is the result of AHP value in pine SAP Administration. The dominant or priority criteria for the development of pine SAP tapping partnership pattern starts with preparing human resources through socialization, mentoring, and training Capital, preparing a cooperation agreement that contains the rights and obligations of the parties involved and conducting ongoing monitoring and evaluation activities.

The application of this partnership pattern of the forest management of central Mamasa is initiated by preparing human resources readiness, preparing the source and. The availability of human resources is a condition for the establishment of an organization and to run the organization requires the budget or source of funds originating from the parties involved.

\section{CONCLUSION}

1. The pattern of the Pine SAP Business Partnership in the forest management of central Mamasa is a partnership pattern of pine SAP tapping between newcomer farmers, PT. Kencana Hijau Bina Lestari, and forest management of central Mamasa 
and a pattern of the pine SAP tapping partnership between Local farmer, capital owner, PT Kencana Hijau Bina Lestari and forest management of central Mamasa.

2. The development direction of the Pine SAP tapping partnership pattern begins with preparing human resources through socialization, mentoring, and training, an investigation of funding sources through partner companies and capital owners, preparing the agreement Cooperation that contains the rights and obligations of the parties involved and conducts ongoing monitoring and evaluation activities

\section{REFERENCE}

[1] Kushartati, B., Sulistya, E., Gamin, Sylvani, Elvida, Y.S., Fentie, S. 2014. Typology and strategies for developing forest management units in Indonesia. Forestry policy journals. 283-298

[2] Saipurrozi, M., Indra, G. F., Hari K. dan Cristine W. 2018. Test the Forestry partnership Program in the forest management Unit XIV Gedong Wani of Lampung province. Journal of Tropical Forests. Vol 6.(1).

[3] PT. Kencana Hijau Bina Lestari. 2018. Production Results Report of pine resin wiretapping Unit Mamasa. Vincent. Province of West Sulawesi

[4] Melawanto Patabang, Nurheni Wijayanto, Hardjanto. 2008. The strategy of pine People's forest development in Tana Toraja. JHMT Vol. XIV, (3) 97-103.

[5] Elva, Kaskoyo, Indra Gumay Febryano, Slamet Budi Yuwono. 2017. Institutional study of Joint Farmer group in partnership Program at KPHP Way Canal. Journal of Tropical Forests. Vol 5 (1).

[6] Kurniadi Edi, Hardjianto, Bramasto Nugroho, Sumardjo. 2013. Institutional of forest management Partnership in West Java province. Journal of Crop Forest Research. Vol 10 (3) 161-171.

[7] Ayulia Putri Cahyani, Markum, Budi Setiawan. 2018. Revenue Contribution in forestry partnership scheme between communities and Perhutani in Forest Pengangkuan Unity (KPH) south of Central Java. Journal, Forestry Study Program of Mataram University

[8] Sugioyono.2014. Qualitative quantitative research methods and R\&D Bandung. Alfabeta

[9] Harisman, K. 2017. The pattern of partnership between farmers with PT. Indofood Fryto-Lay Makmur on Farmer's business potatoes varieties of the Atlantic industry (a case in Cigedug Village Cigedug District Garut. Garuda Portal May edition 2017 Volume X No.1.

[10] Dyah Ethika, Ris Hardi Purwanto., Senawi., dan Mashuri. 2014. Role of farmers on the strategy of forest development in the upstream Sub Das Logawa District in Banyumas, Central Java. Journal of Human and Environmental. Vol 21,(3)

[11] Saaty.T.L. 1993. Decision Making with the analytic hierarchy process. International Journal of service sciences. Vol. 1 